\title{
Aldose Reductase Inhibitors of Plant Origin in the Prevention and Treatment of Alcoholic Liver Disease: A Minireview
}

\author{
Longxin Qiu $\mathbb{D}^{1,2,3}$ Chang Guo, ${ }^{1,2,3}$ and Baoyu Hua ${ }^{1,2,3}$ \\ ${ }^{1}$ School of Life Sciences, Longyan University, Longyan 364012, China \\ ${ }^{2}$ Fujian Province Universities Key Laboratory of Preventive Veterinary Medicine and Biotechnology (Longyan University), \\ Longyan 364012, China \\ ${ }^{3}$ Fujian Provincial Key Laboratory for the Prevention and Control of Animal Infectious Diseases and Biotechnology, \\ Longyan 364012, China
}

Correspondence should be addressed to Longxin Qiu; qlongxin@tom.com

Received 30 March 2019; Accepted 18 May 2019; Published 20 June 2019

Guest Editor: Ranjitsinh V. Devkar

Copyright (C) 2019 Longxin Qiu et al. This is an open access article distributed under the Creative Commons Attribution License, which permits unrestricted use, distribution, and reproduction in any medium, provided the original work is properly cited.

\begin{abstract}
Alcoholic liver disease (ALD) is caused by heavy alcohol consumption over a long period. Acetaldehyde-mediated toxicity, oxidative stress, and imbalance of lipid metabolism are generally considered involved in the initiation of ALD. There is an increasing requirement for alternative and natural medicine to treat ALD. Recently, aldose reductase (AR) has been reported to be involved in the development of ALD by affecting inflammatory cytokines, oxidative stress, and lipid metabolism. Here, we review the effect of plant-derived AR inhibitors on ALD in rodents. And we conclude that AR inhibitors of plant origin may enhance antioxidant capacity, inhibit lipid peroxidation and inflammatory cytokines expression, and activate AMP-activated protein kinase thereby subsequently suppressing alcohol-induced lipid synthesis in liver to achieve ALD protection. This review reveals that natural AR inhibitor may be potential therapeutic agent for ALD.
\end{abstract}

\section{Introduction}

Alcoholic liver disease (ALD) is caused by heavy alcohol consumption over a long period. Metabolism of alcohol in the body produces harmful substances, which lead to liver damage and a series of pathological changes in the liver. The incidence of ALD is relatively high among liver diseases. The spectrum of ALD includes alcoholic fatty liver (AFL), alcoholic steatohepatitis (ASH), progressive fibrosis, cirrhosis, and in some cases hepatocellular cancer (HCC) [1]. AFL is an early stage of ALD and it is usually asymptomatic though some patients have hepatomegaly. ASH exhibits symptoms similar to those of chronic hepatitis, such as mild malaise through the entire body, fatigue, exhaustion, upper abdominal discomfort, nausea and vomiting, loss of appetite, and abdominal distension. Moreover, the severe ASH may lead to alcoholic hepatitis (AH), which is an acute clinical presentation of ALD and requires an effective drug treatment strategy. ASH and AH are terms often used interchangeably in scientific literature [2]. Alcohol abstinence is still the best treatment for all stages of ALD. Drug options for AH include corticosteroids as a first choice and pentoxifylline, an inhibitor of phosphodiesterase, as a second line therapy. In the case of advanced disease such as cirrhosis or HCC, liver transplantation may be required $[1,2]$. Thus, there is an increasing requirement for alternative and natural medicine to treat ALD. Recently, the aldose reductase (AR)/polyol pathway has been reported to be involved in the development of ALD, and treatment with AR inhibitor improves ALD in rodents [3-5]. This article reviews the biological effect of some potent AR inhibitors of plant origin on ALD, and the mechanisms by which AR inhibitors improve ALD.

\section{Pathogenesis of ALD}

The pathogenesis of ALD has not been fully elucidated. Acetaldehyde-mediated toxicity, oxidative stress, and imbalance of lipid metabolism are generally considered involved in the initiation of ALD [6-9]. The "two-hit" theory has been proposed as a model of the pathogenesis of ALD. 
Alcohol, acting as the first hit, increases the concentration of reactive oxides by promoting oxidative stress, which induces fat accumulation in the liver; oxidative stress-related lipid peroxidation and inflammatory cytokines act as the second hit on the hepatocytes in fatty liver, causing inflammation, necrosis, and fibrosis [10].

Many studies have suggested that alcohol-induced imbalance in lipid metabolism may be caused by alcoholinduced abnormal expression of genes involved in lipid metabolism, e.g., peroxisome proliferator-activated receptor alpha (PPAR- $\alpha$ ) or AMP-activated protein kinase (AMPK) expression. PPAR- $\alpha$, a nuclear receptor closely related to lipid metabolism, regulates genes involved in the uptake, binding, transportation, and activation of fatty acids. PPAR$\alpha$ is mainly expressed in hepatocytes and involved in lipid metabolism in the liver. It plays a key role in regulating lipid transport and fatty-acid oxidative degradation in the liver, so it can prevent the development of fatty liver to some extent $[11,12]$. Some studies have confirmed the role of PPAR- $\alpha$ in the development of ALD $[13,14]$. AMPK plays an important role in increasing fatty acid oxidation, enhancing insulin sensitivity, and reducing oxidative stress. It is also closely related to the pathogenesis of ALD [15]. Studies have confirmed that AMPK activity is inhibited in ALD, which weakens the inhibitory effects of acetyl-CoA carboxylase (ACC) and activation of the sterol regulatory element-binding protein (SREBP), resulting in increased lipid synthesis and reduced lipolysis, increased fat accumulation, and the involvement of the "first hit" of ALD pathogenesis. This reduced AMPK expression in ALD may be one of the principal causes of liver damage $[16,17]$.

The oxidative stress that forms during ethanol metabolism is also an important cause of ALD. Ethanol metabolism increases nicotinamide adenine dinucleotide (NADH) levels and electron flow in the electron transport chain in the mitochondria, activating nicotinamide adenine dinucleotide phosphate (NADPH) oxidase (NOX) and microsomal ethanol oxidase system (MEOS) to generate a large quantity of reactive oxygen species (ROS) [9]. In addition, oxidative stress caused by alcohol metabolism induces lipid peroxidation, resulting in further damage to hepatocytes. The lipid peroxidation caused by oxidative stress induces damage to biological membranes, which reduces the concentration of unsaturated fatty acids in the membrane and causes imbalance in the ratio of unsaturated fatty acids to proteins $[6,9]$.

During alcohol metabolism, some antioxidant pathways become activated and so interfere with oxidative stress damage in the human body. For example, the endogenous antioxidant superoxide dismutase (SOD) can interfere with alcoholinduced damage in the liver. Antioxidants such as SOD and catalase in the liver and vitamin $\mathrm{C}$ in food can eliminate a large proportion of ROS produced after alcohol intake. Longterm heavy consumption of alcohol can cause gastrointestinal dysfunction and reduce the absorption of antioxidants from food sources. Further, the process of alcohol metabolism also consumes large quantities of antioxidants, causing ROS to accumulate in the body $[6,7]$.

\section{Aldose Reductase (AR) and ALD}

AR is part of the NADPH-dependent aldehyde-keto reductase superfamily. It is multifunctional and acts as a ratelimiting enzyme of the polyol pathway in sugar metabolism. Through the regulation of cytokines, growth factors, oxidative stress, and other mediated intracellular signal transduction pathways, AR participates in a variety of disease pathological processes [48]. AR is widespread in organs and tissues that are related to diabetic complications, such as the kidney, blood vessels, lens of the eye, retina, and heart. It catalytically converts glucose to sorbitol, which cannot easily pass through the cell membrane, resulting in swelling, degeneration, and necrosis of the cells [49]. The roles of AR in the complications of diabetes have been reported extensively in the literature $[50,51]$.

In addition to being highly expressed in organs and tissues that are relative to diabetic complications, AR expression is also induced in the livers of ALD patients [52] and alcoholstimulated mice [5]. In a previous study, we showed that ARinhibitor treatment improved alcohol-induced steatosis in HepG2 cells by activating AMPK and subsequently inhibiting expression of sterol regulatory element binding protein-1c (SREBP-1c) and fatty acid synthase (FAS). It also inhibited alcohol-mediated tumor necrosis factor alpha (TNF- $\alpha$ ) overexpression to improve alcohol-induced lipid accumulation in hepatocyte [4]. In another previous study, we also showed that AR inhibitor reduced Cytochrome P-450 2E1- (CYP2E1-) mediated oxidative stress and inflammatory cytokine expression, and activated AMPK to improve alcohol-induced hepatic steatosis in mice [5]. Our metabolomics study further demonstrated that AR inhibitor improved alcohol-induced hepatic steatosis in mice by suppressing the biosynthesis of saturated fatty acids [3].

Activation of AR increases the consumption of NADPH and competitively inhibits nitric oxide synthase, which also uses NADPH as a coenzyme. Nitric oxide plays an important role in maintaining the physiological functions of vascular endothelium and nerve tissues. Consumption of large amounts of NADPH causes significant reductions in the amount of nitric oxide synthesized, which ultimately disrupts the reduction-oxidation (redox) system and damages tissue. Increases in NADPH consumption also allow competitive inhibition of the normal synthesis of glutathione (GSH) reductase, which also uses NADPH as a coenzyme, resulting in a significant decrease in the levels of the important antioxidant GSH in cells [53]. Ethanol intake causes damage to the intracellular redox system and a decrease in antioxidant levels, resulting in intracellular oxidative stress and long-term accumulation of fat, thereby leading to ALD [7]. For this reason, it is reasonable to believe that AR plays a vital role in the development of ALD. AR inhibitors may be a suitable resource for the development of drugs for the prevention and treatment of ALD with broad application prospects. 
<smiles>O=C(O)c1c(-c2ccc(O)c(O)c2)oc2cc(O)cc(O)c2c1=O</smiles>

Baicalin<smiles>O=C(O)[C@H]1O[C@@H](Oc2cc3oc(-c4ccccc4)cc(=O)c3c(O)c2O)[C@H](O)[C@@H](O)[C@@H]1O</smiles>

Ellagic acid<smiles>O=c1oc2c(O)c(O)cc3c(=O)oc4c(O)c(O)cc1c4c23</smiles>

Luteolin<smiles>O=c1cc(-c2ccc(O)c(O)c2)oc2cc(O)cc(O)c12</smiles>

Puerarin

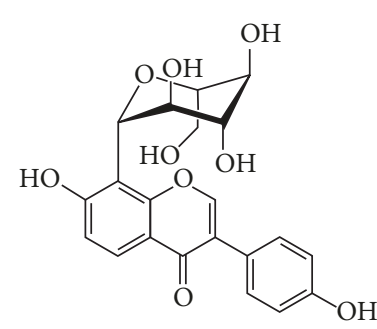

Silymarin<smiles>COc1cc(C2Oc3cc([C@@H]4Oc5cc(O)cc(O)c5C(=O)[C@H]4O)ccc3O[C@H]2CO)ccc1O</smiles>

Apigenin<smiles>O=c1cc(-c2ccc(O)cc2)oc2cc(O)cc(O)c12</smiles>

Genistein<smiles>O=c1c(-c2ccc(O)cc2)coc2cc(O)cc(O)c12</smiles><smiles>COc1cc(/C=C/C(=O)CC(=O)/C=C/c2ccc(O)c(OC)c2)ccc1O</smiles><smiles>COc1cc(/C=C/C(=O)/C=C(O)/C=C/c2ccc(O)c(OC)c2)ccc1O</smiles>

Chlorogenic acid<smiles>O=C(/C=C/c1ccc(O)c(O)c1)OC1CC(O)(C(=O)O)C[C@@H](O)[C@@H]1O</smiles>

FIgURE 1: Chemical structure of some potent AR inhibitors of plant origin.

\section{Role of Plant-Derived AR Inhibitors in the Prevention and Treatment of ALD}

AR inhibitors are generally divided into three categories according to the sources: natural AR inhibitors of plant origin, natural AR inhibitors of microbial origin, and synthetic AR inhibitors such as carboxylic acids, hydantoins, and phenylpyrrolidone compounds. Among the three categories of AR inhibitors, plant AR inhibitors, which mainly include flavonoids, polyphenols, terpenoids, and alkaloids, have seen widespread use because of their wide range of sources and low rate of adverse reactions. Plant-derived compounds with AR inhibitory effect have been extensively reviewed by Veeresham et al. [51] and Kawanishi et al. [54]. Among these compounds, currently only some commercially available ones have been tested for hepatoprotection activity in rodents with ethanol-induced liver injury and are summarized in Table 1 in this review. The AR inhibitory activities of these compounds have been well documented. In a study, more than 90 compounds from several natural medicines and medicinal foodstuffs were examined for their AR inhibitory effect on rat lens AR; among them, quercitrin (IC50=0.15 $\mu \mathrm{M}$ ), guaijaverin $(\mathrm{IC} 50=0.18 \mu \mathrm{M})$, and desmanthin-1 (IC50=0.082 $\mu \mathrm{M}$ ) exhibited potent inhibitory activity on rat lens AR [55]. However, some commercially available flavonoids, including luteolin, quercetin, apigenin, fisetin, and myricitrin, were also found to have strong AR inhibitory activities with
IC50 values of $0.45 \mu \mathrm{M}, 2.2 \mu \mathrm{M}, 2.2 \mu \mathrm{M}, 3.7 \mu \mathrm{M}$, and 3.8 $\mu \mathrm{M}$ respectively, although their activities were weaker than epalrestat, a commercial synthetic aldose reductase inhibitor that inhibits AR with an IC50 of $0.172 \mu \mathrm{M}$. In another study, a phenolics, ellagic acid, isolated from Chrysanthemum morifolium exhibited inhibitory activity with an IC50 of $0.2 \mu \mathrm{M}$, which is stronger than that of quercetin $(1.2 \mu \mathrm{M})$ in this study [56]. These studies demonstrate that luteolin, quercetin, apigenin, rhamnetin, fisetin, myricitrin, and ellagic acid are potent AR inhibitors. Moreover, silybin, puerarin, and baicalin were found to exhibit markedly inhibitory effects on AR comparable to sorbinil, another commercial synthetic aldose reductase inhibitor [57]. In addition, genistein, puerarin and baicalin were reported to inhibit rat lens AR with IC50 values of $4.5 \mu \mathrm{M}, 44.7 \mu \mathrm{M}$, and $25.1 \mu \mathrm{M}$, respectively [58]. And curcumin inhibits AR with an IC50 of $10 \mu \mathrm{M}$ in a noncompetitive manner in one study [59], or with an IC50 of $6.8 \mu \mathrm{M}$ in the other study [60]. Chlorogenic acid, another phenolic compound, was also reported to inhibit rat AR with an IC50 of $0.95 \mu \mathrm{M}$ [61]. These studies demonstrate that luteolin, quercetin, apigenin, fisetin, myricitrin, genistein, silymarin/silybin, ellagic acid, curcumin, and chlorogenic acid are potent AR inhibitors. The chemical structures of these compounds are depicted in Figure 1.

Previously we demonstrated that zopolrestat, a chemically synthesized AR inhibitor, improved ethanol-induced liver injury in mice through suppressing oxidative stress, 
TABLE 1: Effects of some natural AR inhibitors on ALD in rodents.

\begin{tabular}{|c|c|c|c|}
\hline Treatment & Experimental model & Effects & Ref. \\
\hline Quercetin & $\begin{array}{l}\text { Rats treated with } 50 \% \text { ethanol for } 10 \\
\text { days }\end{array}$ & $\begin{array}{l}\text { Prevents ethanol-induced liver injury by enhancing } \\
\text { antioxidative activity and suppressing the induction of } \\
\text { cytokines, chemokines }\end{array}$ & Chen et al. [18] \\
\hline Quercetin & $\begin{array}{l}\text { Rats administrated with alcohol }(4.0 \\
\mathrm{g} / \mathrm{kg}) \text { for } 90 \text { days }\end{array}$ & $\begin{array}{l}\text { Protects against chronic ethanol toxicity through its } \\
\text { hypolipidemic effect and antioxidative role }\end{array}$ & Tang et al. [19] \\
\hline Quercetin & $\begin{array}{l}\text { Rats administrated with alcohol }(4.0 \\
\mathrm{g} / \mathrm{kg}) \text { for } 90 \text { days }\end{array}$ & $\begin{array}{l}\text { Attenuates ethanol-derived microsomal oxidative stress } \\
\text { by suppressing the downregulation of HO-1 and the } \\
\text { induction of CYP2E1 }\end{array}$ & Tang et al. [20] \\
\hline Quercetin & $\begin{array}{l}\text { Rats treated with ethanol }(2.0 \mathrm{~g} / \mathrm{kg}) \\
\text { for } 30 \text { days }\end{array}$ & $\begin{array}{l}\text { Prevents long-term alcohol consumption-induced } \\
\text { oxidative stress and cytokines }\end{array}$ & Kahraman et al. [21] \\
\hline Quercetin & $\begin{array}{l}\text { Mice fed with Lieber-deCarli } \\
\text { alcohol-liquid diets for } 15 \text { weeks }\end{array}$ & $\begin{array}{c}\text { Alleviates ethanol-elicited mitochondrial damage } \\
\text { through enhancing AMPK- and ERK2-mediated } \\
\text { mitophagy }\end{array}$ & Yu et al. [22] \\
\hline Luteolin & $\begin{array}{l}\text { Mice exposed to alcohol }(1 \%, 2 \% \text {, and } \\
4 \% \text { for } 3 \mathrm{~d} \text {, and } 5 \% \text { for } 9 \mathrm{~d} \text { ) and a } \\
\text { binge ( } 30 \% \text { ethanol) on the last day }\end{array}$ & $\begin{array}{c}\text { Ameliorates ethanol-induced hepatic steatosis and injury } \\
\text { by activating AMPK and suppressing SREBP-1c/FAS } \\
\text { pathway }\end{array}$ & Liu et al. [23] \\
\hline Apigenin & $\begin{array}{l}\text { Mice given } 56 \% \text { erguotou wine by } \\
\text { gavage for } 30 \text { days }\end{array}$ & $\begin{array}{l}\text { Exerts a protective effect on alcohol-induced liver injury } \\
\text { by regulating hepatic CYP2E1-mediated oxidative stress } \\
\text { and PPAR } \alpha \text {, SREBP-1c and FAS gene expression }\end{array}$ & Wang et al. [24] \\
\hline Fisetin & $\begin{array}{l}\text { Mice given } 50 \% \text { ethanol p.o. } \\
\text { (10 ml/kg body weight) every } 12 \\
\text { hours for a total of } 5 \text { doses }\end{array}$ & $\begin{array}{l}\text { Ameliorate alcohol-induced hepatic damage by restoring } \\
\text { the antioxidant and MMP/TIMP balance }\end{array}$ & Koneru et al. [25] \\
\hline Fisetin & $\begin{array}{l}\text { Mice fed with Lieber-deCarli } \\
\text { alcohol-liquid diets for } 4 \text { weeks }\end{array}$ & $\begin{array}{c}\text { Attenuates alcohol-induced hepatic steatosis by } \\
\text { increasing hepatic protein levels of p-AMPK, ACOX1, } \\
\text { CYP4A, and MTTP }\end{array}$ & Sun et al. [26] \\
\hline Baicalin & $\begin{array}{c}\text { Rats intragastrically administrated } \\
\text { with alcohol continuously for } 4 \text { or } 8 \\
\text { weeks }\end{array}$ & $\begin{array}{c}\text { Exerts beneficial effects on alcohol-induced liver injury } \\
\text { through inhibiting oxidative stress, proinflammatory } \\
\text { cytokines expression, and the regulation of the sonic } \\
\text { hedgehog pathway }\end{array}$ & Wang et al. [27] \\
\hline Baicalin & $\begin{array}{l}\text { Mice treated by chronic plus binge } \\
\text { ethanol feeding }\end{array}$ & $\begin{array}{l}\text { Ameliorates ethanol-induced liver injury by modulating } \\
\text { oxidative stress and inflammation via CYP2E1 and NRF2 }\end{array}$ & He et al. [28] \\
\hline Puerarin & $\begin{array}{l}\text { Rats treated with } 40 \% \text { ethanol ( } 8 \\
\text { g/kg/d) for } 5 \text { days }\end{array}$ & Prevents acute ALD by enhancing antioxidative capacity & Zhao et al. [29] \\
\hline Puerarin & $\begin{array}{l}\text { Rats provided with the Liber-deCarli } \\
\text { liquid diet for } 8 \text { weeks }\end{array}$ & $\begin{array}{l}\text { Alleviates chronic alcoholic liver injury by inhibiting } \\
\text { endotoxin gut leakage, Kupffer cell activation, and } \\
\text { endotoxin receptors expression }\end{array}$ & Peng et al. [30] \\
\hline Puerarin & $\begin{array}{l}\text { Rats treated with } 6 \mathrm{~g} / \mathrm{kg} / \mathrm{d}, 7 \mathrm{~g} / \mathrm{kg} / \mathrm{d}, 8 \\
\mathrm{~g} / \mathrm{kg} / \mathrm{d} \text { (for a period of } 1 \text { week } \\
\text { respectively), and } 9 \mathrm{~g} / \mathrm{kg} / \mathrm{d} \text { (for a } \\
\text { period of } 21 \text { weeks) of } 56 \% \text { alcohol }\end{array}$ & $\begin{array}{l}\text { Protects against alcohol-induced liver lesions through } \\
\text { improving metabolic function }\end{array}$ & Chen et al. [31] \\
\hline $\begin{array}{l}\text { Puerarin/ } \\
\text { Genistein }\end{array}$ & $\begin{array}{l}\text { Mice gastrically infused with } 50 \% \\
\text { alcohol once per day for } 5 \text { weeks }\end{array}$ & $\begin{array}{l}\text { Alleviates hepatic damage induced by chronic alcohol } \\
\text { administration through potential antioxidant, } \\
\text { anti-inflammatory, or anti-apoptotic mechanisms }\end{array}$ & Zhao et al. [32] \\
\hline Genistein & $\begin{array}{l}\text { Rats underwent intragastric } \\
\text { administration of alcohol }(5.0-9.5 \\
\mathrm{g} / \mathrm{kg}) \text { once a day for } 24 \text { weeks }\end{array}$ & $\begin{array}{l}\text { Ameliorates ethanol-induced liver injury and even liver } \\
\text { fibrosis by decreasing oxidative stress and production of } \\
\text { inflammatory and by inhibiting fibrogenic mediators }\end{array}$ & Huang et al. [33] \\
\hline Curcumin & $\begin{array}{l}\text { Rats treated with ethanol (starting } \\
\text { dose was } 8 \mathrm{~g} / \mathrm{kg} / \mathrm{d} \text { and final dose was } \\
16 \mathrm{~g} / \mathrm{kg} / \mathrm{d} \text { ) plus fish oil for } 4 \text { weeks }\end{array}$ & $\begin{array}{l}\text { Prevents experimental ALD by suppressing the activation } \\
\text { of NF- } \kappa \mathrm{B} \text { and the induction of cytokines, chemokines }\end{array}$ & Nanji et al. [34] \\
\hline Curcumin & $\begin{array}{c}\text { Mice treated with ethanol }(2.4 \\
\mathrm{g} / \mathrm{kg} / \text { day ethanol for the initial } 4 \\
\text { weeks and } 4 \mathrm{~g} / \mathrm{kg} / \text { day for another } 2 \\
\text { weeks) }\end{array}$ & $\begin{array}{l}\text { Prevents chronic ALD by decreasing ROS generation and } \\
\text { enhancing antioxidative capacity }\end{array}$ & Rong et al. [35] \\
\hline Curcumin & $\begin{array}{l}\text { Mice administered orally with } \\
\text { alcohol }(5 \mathrm{~g} / \mathrm{kg} \text { body weight }) \text { once a } \\
\text { day for } 6 \text { weeks and fed a high-fat diet }\end{array}$ & $\begin{array}{l}\text { Protects alcohol-induced liver damage by modulating } \\
\text { alcohol metabolic pathway, enhancing antioxidant } \\
\text { activity and activating AMPK }\end{array}$ & Lee et al. [36] \\
\hline
\end{tabular}


TABLE 1: Continued.

\begin{tabular}{|c|c|c|c|}
\hline Treatment & Experimental model & Effects & Ref. \\
\hline Curcumin & $\begin{array}{c}\text { Rats given ethanol }(56 \% \mathrm{v} / \mathrm{v}, 10 \\
\mathrm{mL} / \mathrm{kg}) \text { orally once every day for } 9 \\
\text { weeks }\end{array}$ & $\begin{array}{l}\text { Attenuates ALD by modulating lipid deposition in } \\
\text { hepatocytes via a Nrf2/FXR activation and modulating the } \\
\text { expression of SREBP-1c, fatty acid synthase, and PPAR- } \alpha\end{array}$ & Lu et al. [37] \\
\hline Curcumin & $\begin{array}{l}\text { Mice given } 2.4 \mathrm{~g} / \mathrm{kg} / \text { day ethanol plus } \\
\text { olive oil once a day for } 6 \text { weeks }\end{array}$ & $\begin{array}{c}\text { Protects the liver from chronic-ethanol induced injury } \\
\text { through attenuating oxidative stress, at least partially, } \\
\text { through ERK/p38/Nrf2-mediated anti-oxidant signaling } \\
\text { pathways }\end{array}$ & Xiong et al. [38] \\
\hline Curcumin & $\begin{array}{l}\text { Rats fed with Lieber-deCarli low } \\
\text { menhaden and high menhaden } \\
\text { alcohol-liquid diets for } 8 \text { weeks }\end{array}$ & $\begin{array}{l}\text { Protects against chronic alcohol-induced liver injury by } \\
\text { enhancing antioxidative capacity }\end{array}$ & Varatharajalu et al. [39] \\
\hline Curcumin & $\begin{array}{l}\text { Mice fed with Lieber-deCarli } \\
\text { alcohol-liquid diets for } 4 \text { weeks }\end{array}$ & $\begin{array}{l}\text { Improves alcoholic fatty liver by inhibiting biosynthesis of } \\
\text { unsaturated fatty acids, fatty acid biosynthesis and pentose } \\
\text { and glucuronate interconversions }\end{array}$ & Guo et al. [40] \\
\hline Curcumin & $\begin{array}{c}\text { Rats fed } 50 \% \text { ethanol }(7.5 \mathrm{~g} / \mathrm{kg} \text { body } \\
\text { weight/day) orally twice a day for } 4 \\
\text { weeks }\end{array}$ & $\begin{array}{l}\text { Improves ethanol-induced liver injury by reducing } \\
\text { oxidative stress and inhibiting NF- } \kappa \text { B activation }\end{array}$ & Samuhasaneeto et al. [41] \\
\hline Ellagic acid & $\begin{array}{l}\text { Rats fed } 20 \% \text { alcohol orally ( } 7.9 \mathrm{~g} / \mathrm{kg} \\
\text { body weight) for } 45 \text { days }\end{array}$ & Exerts beneficial effects against alcohol-induced damage & Devipriya et al. [42] \\
\hline Ellagic acid & $\begin{array}{l}\text { Rats fed } 20 \% \text { alcohol orally }(7.9 \mathrm{~g} / \mathrm{kg} \\
\text { body weight) for } 45 \text { days }\end{array}$ & $\begin{array}{l}\text { Decreases the expression pattern of fibrotic markers during } \\
\text { alcohol-induced toxicity }\end{array}$ & Devipriya et al. [43] \\
\hline Ellagic acid & $\begin{array}{l}\text { Mice fed with Lieber-deCarli } \\
\text { alcohol-liquid diets for } 5 \text { weeks }\end{array}$ & $\begin{array}{l}\text { Improves alcoholic fatty liver by suppressing the expression } \\
\text { of the genes related to cell stress and up-regulating the } \\
\text { genes involved in bile acid synthesis, unsaturated fatty acid } \\
\text { elongation, and tetrahydrofolate synthesis }\end{array}$ & Yao et al. [44] \\
\hline $\begin{array}{l}\text { Silymarin } \\
\text { /Silybin }\end{array}$ & $\begin{array}{l}\text { Mice received ethanol }(5 \mathrm{~g} / \mathrm{kg} \text { body } \\
\text { weight) by gavage every } 12 \text { hours for a } \\
\text { total of } 3 \text { doses }\end{array}$ & $\begin{array}{c}\text { Protects against the acute alcoholic liver injury by } \\
\text { decreasing oxidative stress and production of inflammatory } \\
\text { cytokines }\end{array}$ & Song et al. [45] \\
\hline $\begin{array}{l}\text { Silymarin } \\
\text { /Silybin }\end{array}$ & $\begin{array}{l}\text { Mice fed ethanol }(1.6 \mathrm{~g} / \mathrm{kg} \text { body } \\
\text { weight) for } 12 \text { weeks }\end{array}$ & $\begin{array}{l}\text { Prevents long-term alcohol consumption-induced liver } \\
\text { injury by enhancing antioxidant activity and suppressing } \\
\text { the induction of cytokines }\end{array}$ & Das et al. [46] \\
\hline $\begin{array}{l}\text { Chlorogenic } \\
\text { acid }\end{array}$ & $\begin{array}{l}\text { Mice fed ethanol ( } 3 \mathrm{~g} / \mathrm{kg} \text { body } \\
\text { weight) for } 7 \text { consecutive days }\end{array}$ & $\begin{array}{l}\text { Prevents ethanol-induced acute liver injury by reducing } \\
\text { oxidative stress, steatosis, apoptotic cell death, and fibrosis }\end{array}$ & Kim et al. [47] \\
\hline
\end{tabular}

reducing proinflammatory cytokines expression and modulating AMPK/SREBP-1c pathway to attenuate fatty acid synthesis [5]. The same mechanisms whereby zopolrestat improves lipid accumulation were also demonstrated in ethanol-intoxicated mouse AML12 liver cells [5] and human hepatoma HepG2 cells [4]. Of note, among the plant-derived AR inhibitors which were found to exert hepatoprotection effect in rodents, all of them were at least in part through potential antioxidant and anti-inflammatory mechanisms. A recent work reported that chlorogenic acid ameliorated ethanol-induced reactive oxygen species and subsequently reduced hepatic steatosis in mice [47]. Moreover, luteolin, quercetin, apigenin, fisetin, and curcumin were demonstrated to alleviate hepatic steatosis through modulating AMPK/SREBP-1c pathway. Besides these in vivo studies, some in vitro studies also demonstrated that AR inhibitors from nature, including myricitrin [62], puerarin [63], and isoliquiritigenin [64], protected ethanol-intoxicated hepatocytes by regulating the AMPK signaling pathway. In addition, phenolic acid and flavonoid rich ethyl acetate fraction of $S$. quelpaertensis extract (SQEA) was reported to exert cytoprotective effect against ethanol-induced toxicity in HepG2 cells and exhibit antisteatosis effect via the activation of AMPK signaling pathway in alcohol challenged livers [65]. Interestingly, $\mathrm{p}$-coumaric acid and rutin, myricetin were the predominant phenolic acid and flavonoid in SQEA, and they are all AR inhibitors. These studies together demonstrate that AR inhibitors from plant protect against alcoholinduced liver injury through the similar mechanisms with those of chemical synthesized AR inhibitor and indicate that AR inhibitors from nature may be a promising source for developing anti-ALD drugs.

\section{Conclusion}

In summary, as depicted in Figure 2, AR participates in the development of ALD by affecting inflammatory cytokines, oxidative stress, and lipid metabolism in liver while natural AR inhibitors may reduce inflammation, enhance antioxidant activation, inhibit lipid peroxidation, and suppress alcoholinduced lipid synthesis through activating AMPK in liver to achieve ALD protection. This review provides a theoretical basis for the use of natural AR inhibitors in the prevention and treatment of ALD. 

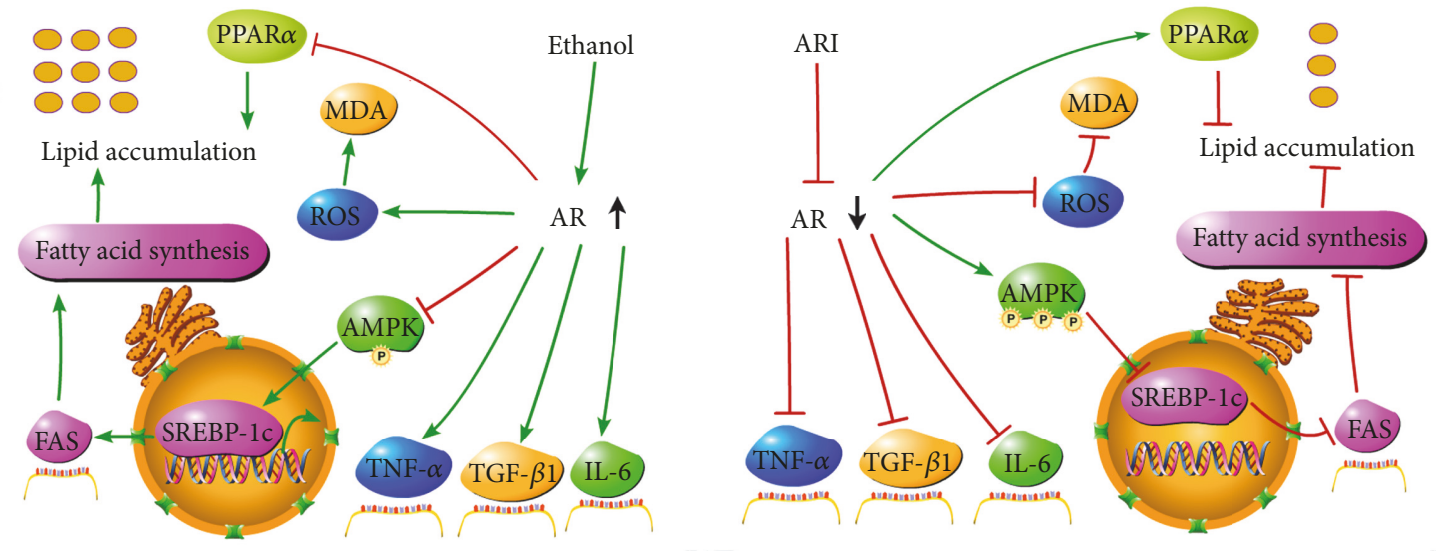

FIGURE 2: Schematic showing the mechanisms by which aldose reductase inhibitors prevent ALD. AR, aldose reductase; ARI, AR inhibitors; AMPK, AMP-activated protein kinase; SREBP-1c, sterol regulatory element binding protein-1c; FAS, fatty acid synthase.

\section{Conflicts of Interest}

The authors declare no conflict of interest.

\section{Acknowledgments}

This work was supported by Educational Commission of Fujian Province, China (grant no JT180534) and the Natural Science Foundation of Fujian Province, China (grant no 2019J01802). We would like to thank LetPub (https://www letpub.com) for providing linguistic assistance during the preparation of this manuscript.

\section{References}

[1] H. K. Seitz, R. Bataller, H. Cortez-Pinto et al., "Alcoholic liver disease," Nature Reviews Disease Primers, vol. 4, no. 1, p. 16, 2018.

[2] R. Teschke, "Alcoholic steatohepatitis (ASH) and alcoholic hepatitis (AH): cascade of events, clinical aspects, and pharmacotherapy options," Expert Opinion on Pharmacotherapy, vol. 19, no. 8, pp. 779-793, 2018.

[3] C. Guo, L. Chen, J. Huang et al., "Aldose reductase inhibitor protects mice from alcoholic steatosis by repressing saturated fatty acid biosynthesis," Chemico-Biological Interactions, vol. 287, pp. 41-48, 2018.

[4] L. Qiu, C. Cai, X. Zhao, Y. Fang, W. Tang, and C. Guo, "Inhibition of aldose reductase ameliorates ethanol-induced steatosis in HepG2 cells," Molecular Medicine Reports, vol. 15, no. 5, pp. 2732-2736, 2017.

[5] C. Shi, Y. Wang, J. Gao et al., "Inhibition of aldose reductase ameliorates alcoholic liver diseaseby activating AMPK and modulating oxidative stressand inflammatory cytokines," Molecular Medicine Reports, vol. 16, no. 3, pp. 2767-2772, 2017.

[6] S. Li, H. Y. Tan, N. Wang et al., "The role of oxidative stress and antioxidants in liver diseases," International Journal of Molecular Sciences, vol. 16, no. 11, pp. 26087-26124, 2015.

[7] K.-H. Han, N. Hashimoto, and M. Fukushima, "Relationships among alcoholic liver disease, antioxidants, and antioxidant enzymes," World Journal of Gastroenterology, vol. 22, no. 1, pp. 37-49, 2016.
[8] K. Sugimoto and Y. Takei, "Pathogenesis of alcoholic liver disease," Hepatology Research, vol. 47, no. 1, pp. 70-79, 2017.

[9] A. Louvet and P. Mathurin, "Alcoholic liver disease: mechanisms of injury and targeted treatment," Nature Reviews Gastroenterology \& Hepatology, vol. 12, no. 4, pp. 231-242, 2015.

[10] H. Tsukamoto, K. Machida, A. Dynnyk, and H. Mkrtchyan, "“Second hit" models of alcoholic liver disease," Seminars in Liver Disease, vol. 29, no. 2, pp. 178-187, 2009.

[11] N. Bougarne, B. Weyers, S. J. Desmet et al., "Molecular actions of PPAR $\alpha$ in lipid metabolism and inflammation," Endocrine Reviews, vol. 39, no. 5, pp. 760-802, 2018.

[12] W. Fan and R. Evans, "PPARs and ERRs: molecular mediators of mitochondrial metabolism," Current Opinion in Cell Biology, vol. 33, pp. 49-54, 2015.

[13] F. A. R. Lívero and A. Acco, "Molecular basis of alcoholic fatty liver disease: From incidence to treatment," Hepatology Research, vol. 46, no. 1, pp. 111-123, 2016.

[14] D. W. Crabb, A. Galli, M. Fischer, and M. You, "Molecular mechanisms of alcoholic fatty liver: Role of peroxisome proliferatoractivated receptor alpha," Alcohol, vol. 34, no. 1, pp. 35-38, 2004.

[15] M. S. Sozio, S. Liangpunsakul, and D. Crabb, “The role of lipid metabolism in the pathogenesis of alcoholic and nonalcoholic hepatic steatosis," Seminars in Liver Disease, vol. 30, no. 4, pp. 378-390, 2010.

[16] B. Sid, J. Verrax, and P. B. Calderon, "Role of AMPK activation in oxidative cell damage: Implications for alcohol-induced liver disease," Biochemical Pharmacology, vol. 86, no. 2, pp. 200-209, 2013.

[17] Z. Jiang, J. Zhou, D. Zhou, Z. Zhu, L. Sun, and A. A. Nanji, “The adiponectin-SIRT1-AMPK pathway in alcoholic fatty liver disease in the rat," Alcoholism: Clinical and Experimental Research, vol. 39, no. 3, pp. 424-433, 2015.

[18] X. Chen, "Protective effects of quercetin on liver injury induced by ethanol," Pharmacognosy Magazine, vol. 6, no. 22, pp. 135$141,2010$.

[19] Y. Tang, C. Gao, M. Xing et al., "Quercetin prevents ethanolinduced dyslipidemia and mitochondrial oxidative damage," Food and Chemical Toxicology, vol. 50, no. 5, pp. 1194-1200, 2012.

[20] Y. H. Tang, C. Gao, Y. R. Shi et al., "Quercetin attenuates ethanol-derived microsomal oxidative stress: implication of haem oxygenase-1 induction," Food Chemistry, vol. 132, no. 4, pp. 1769-1774, 2012. 
[21] A. Kahraman, H. Cakar, and T. Köken, "The protective effect of quercetin on long-term alcohol consumption-induced oxidative stress," Molecular Biology Reports, vol. 39, no. 3, pp. 27892794, 2012.

[22] X. Yu, Y. Xu, S. Zhang et al., "Quercetin attenuates chronic ethanol-induced hepatic mitochondrial damage through enhanced mitophagy," Nutrients, vol. 8, no. 1, 2016.

[23] G. Liu, Y. Zhang, C. Liu et al., "Luteolin alleviates alcoholic liver disease induced by chronic and binge ethanol feeding in mice," Journal of Nutrition, vol. 144, no. 7, pp. 1009-1015, 2014.

[24] F. Wang, J.-C. Liu, R.-J. Zhou et al., "Apigenin protects against alcohol-induced liver injury in mice by regulating hepatic CYP2E1-mediated oxidative stress and PPAR $\alpha$-mediated lipogenic gene expression," Chemico-Biological Interactions, vol. 275, pp. 171-177, 2017.

[25] M. Koneru, B. D. Sahu, J. M. Kumar et al., "Fisetin protects liver from binge alcohol-induced toxicity by mechanisms including inhibition of matrix metalloproteinases (MMPs) and oxidative stress," Journal of Functional Foods, vol. 22, pp. 588-601, 2016.

[26] Q. Sun, W. Zhang, W. Zhong, X. Sun, and Z. Zhou, "Dietary fisetin supplementation protects against alcohol-induced liver injury in mice," Alcoholism: Clinical and Experimental Research, vol. 40, no. 10, pp. 2076-2084, 2016.

[27] H. Wang, Y. Zhang, R. Bai, M. Wang, and S. Du, "Baicalin attenuates alcoholic liver injury through modulation of hepatic oxidative stress, inflammation and sonic hedgehog pathway in rats," Cellular Physiology and Biochemistry, vol. 39, no. 3, pp. 1129-1140, 2016.

[28] P. He, Y. Wu, J. Shun, Y. Liang, M. Cheng, and Y. Wang, "Baicalin ameliorates liver injury induced by chronic plus binge ethanol feeding by modulating oxidative stress and inflammation via CYP2E1 and NRF2 in mice," Oxidative Medicine and Cellular Longevity, vol. 2017, Article ID 4820414, 2017.

[29] M. Zhao, Y.-Q. Du, L. Yuan, and N.-N. Wang, "Protective effect of puerarin on acute alcoholic liver injury," American Journal of Chinese Medicine, vol. 38, no. 2, pp. 241-249, 2010.

[30] J. Peng, T. Cui, F. Huang et al., "Puerarin ameliorates experimental alcoholic liver injury by inhibition of endotoxin gut leakage, Kupffer cell activation, and endotoxin receptors expression," The Journal of Pharmacology and Experimental Therapeutics, vol. 344, no. 3, pp. 646-654, 2013.

[31] X. Chen, R. Li, T. Liang, K. Zhang, Y. Gao, and L. Xu, "Puerarin improves metabolic function leading to hepatoprotective effects in chronic alcohol-induced liver injury in rats," Phytomedicine, vol. 20, no. 10, pp. 849-852, 2013.

[32] L. Zhao, Y. Wang, J. Liu et al., "Protective effects of genistein and puerarin against chronic alcohol-induced liver injury in mice via antioxidant, anti-inflammatory, and anti-apoptotic mechanisms," Journal of Agricultural and Food Chemistry, vol. 64, no. 38, pp. 7291-7297, 2016.

[33] Q. Huang, R. Huang, S. Zhang et al., "Protective effect of genistein isolated from Hydrocotyle sibthorpioides on hepatic injury and fibrosis induced by chronic alcohol in rats," Toxicology Letters, vol. 217, no. 2, pp. 102-110, 2013.

[34] A. A. Nanji, K. Jokelainen, G. L. Tipoe, A. Rahemtulla, P. Thomas, and A. J. Dannenberg, "Curcumin prevents alcoholinduced liver disease in rats by inhibiting the expression of NF- $\kappa \mathrm{B}$-dependent genes," American Journal of PhysiologyGastrointestinal and Liver Physiology, vol. 284, no. 2, pp. G321G327, 2003.
[35] S. Rong, Y. Zhao, W. Bao et al., "Curcumin prevents chronic alcohol-induced liver disease involving decreasing ROS generation and enhancing antioxidative capacity," Phytomedicine, vol. 19, no. 6, pp. 545-550, 2012.

[36] H.-I. Lee, R. A. McGregor, M.-S. Choi et al., "Low doses of curcumin protect alcohol-induced liver damage by modulation of the alcohol metabolic pathway, CYP2E1 and AMPK," Life Sciences, vol. 93, no. 18-19, pp. 693-699, 2013.

[37] C. Lu, F. Zhang, W. Xu et al., "Curcumin attenuates ethanolinduced hepatic steatosis through modulating Nrf2/FXR signaling in hepatocytes," IUBMB Life, vol. 67, no. 8, pp. 645-658, 2015.

[38] Z. E. Xiong, W. G. Dong, B. Y. Wang, Q. Y. Tong, and Z. Y. $\mathrm{Li}$, "Curcumin attenuates chronic ethanol-induced liver injury by inhibition of oxidative stress via mitogen-activated protein kinase/nuclear factor E2-related factor 2 pathway in mice," Pharmacognosy Magazine, vol. 11, no. 44, pp. 707-715, 2015.

[39] R. Varatharajalu, M. Garige, L. C. Leckey, K. Reyes-Gordillo, R. Shah, and M. R. Lakshman, "Protective role of dietary curcumin in the prevention of the oxidative stress induced by chronic alcohol with respect to hepatic injury and antiatherogenic markers," Oxidative Medicine and Cellular Longevity, vol. 2016, Article ID 5017460, 10 pages, 2016.

[40] C. Guo, J. Ma, Q. Zhong et al., "Curcumin improves alcoholic fatty liver by inhibiting fatty acid biosynthesis," Toxicology and Applied Pharmacology, vol. 328, pp. 1-9, 2017.

[41] S. Samuhasaneeto, D. Thong-Ngam, O. Kulaputana, D. Suyasunanont, and N. Klaikeaw, "Curcumin decreased oxidative stress, inhibited nf-k b activation, and improved liver pathology in ethanol-induced liver injury in rats," Journal of Biomedicine and Biotechnology, vol. 2009, Article ID 981963, 2009.

[42] N. Devipriya, A. R. Sudheer, P. Vishwanathan, and V. P. Menon, "Modulatory potential of ellagic acid, a natural plant polyphenol on altered lipid profile and lipid peroxidation status during alcohol-induced toxicity: A pathohistological study," Journal of Biochemical and Molecular Toxicology, vol. 22, no. 2, pp. 101-112, 2008.

[43] N. Devipriya, A. R. Sudheer, M. Srinivasan, and V. P. Menon, "Effect of ellagic acid, a plant polyphenol, on fibrotic markers (MMPs and TIMPs) during alcohol-induced hepatotoxicity," Toxicology Mechanisms and Methods, vol. 17, no. 6, pp. 349-356, 2007.

[44] R. Yao, A. Yasuoka, A. Kamei et al., "Nuclear receptor-mediated alleviation of alcoholic fatty liver by polyphenols contained in alcoholic beverages," PLoS ONE, vol. 9, no. 2, Article ID e87142, 2014.

[45] Z. Song, I. Deaciuc, M. Song et al., "Silymarin protects against acute ethanol-induced hepatotoxicity in mice," Alcoholism: Clinical and Experimental Research, vol. 30, no. 3, pp. 407-413, 2006.

[46] S. K. Das and S. Mukherjee, "Biochemical and immunological basis of silymarin effect, a milk thistle (Silybum marianum) against ethanol-induced oxidative damage," Toxicology Mechanisms and Methods, vol. 22, no. 5, pp. 409-413, 2012.

[47] H. Kim, J. H. Pan, S. H. Kim, J. H. Lee, and J.-W. Park, "Chlorogenic acid ameliorates alcohol-induced liver injuries through scavenging reactive oxygen species," Biochimie, vol. 150, pp. 131-138, 2018.

[48] T. M. Penning, "The aldo-keto reductases (AKRs): Overview," Chemico-Biological Interactions, vol. 234, pp. 236-246, 2015.

[49] W. H. Tang, K. A. Martin, and J. Hwa, "Aldose reductase, oxidative stress, and diabetic mellitus," Frontiers in Pharmacology, vol. 3, article 87, 2012. 
[50] A. S. Grewal, S. Bhardwaj, D. Pandita, V. Lather, and B. S. Sekhon, "Updates on aldose reductase inhibitors for management of diabetic complications and non-diabetic diseases," Mini-Reviews in Medicinal Chemistry, vol. 16, no. 2, pp. 120-162, 2016.

[51] C. Veeresham, A. R. Rao, and K. Asres, "Aldose reductase inhibitors of plant origin," Phytotherapy Research, vol. 28, no. 3, pp. 317-333, 2014.

[52] K. E. Brown, K. A. Broadhurst, M. M. Mathahs et al., "Immunodetection of aldose reductase in normal and diseased human liver," Histology and Histopathology, vol. 20, no. 2, pp. 429-436, 2005.

[53] P. A. Barnett, R. G. Gonzalez, L. T. Chylack Jr., and H. M. Cheng, "The effect of oxidation on sorbitol pathway kinetics," Diabetes, vol. 35, no. 4, pp. 426-432, 1986.

[54] K. Kawanishi, H. Ueda, and M. Moriyasu, "Aldose reductase inhibitors from the nature," Current Medicinal Chemistry, vol. 10, no. 15, pp. 1353-1374, 2003.

[55] H. Matsuda, T. Morikawa, I. Toguchida, and M. Yoshikawa, "Structural requirements of flavonoids and related compounds for aldose reductase inhibitory activity," Chemical \& Pharmaceutical Bulletin, vol. 50, no. 6, pp. 788-795, 2002.

[56] S. Terashtma, M. Shimizu, S. Horie, and N. Morita, "Studies on aldose reductase inhibitors from natural products: IV: constituents and aldose reductase inhibitory effect of chrysanthemum morifolium, bixa orellana and ipomoea batatas," Chemical \& Pharmaceutical Bulletin, vol. 39, no. 12, pp. 3346-3347, 1991.

[57] J. Q. Zhang and Y. P. Zhou, "Inhibition of aldose reductase from rat lens by some Chinese herbs and their components," China Journal of Chinese Materia Medica, vol. 14, no. 9, pp. 557-576, 1989.

[58] C.-H. Park, S. L. Soon, and D.-U. Lee, "Structure-activity relationships of components from the roots of pueraria thunbergiana having aldose reductase inhibitory and antioxidative activity," Bulletin of the Korean Chemical Society, vol. 28, no. 3, pp. 493-495, 2007.

[59] P. Muthenna, P. Suryanarayana, S. K. Gunda, J. M. Petrash, and G. B. Reddy, "Inhibition of aldose reductase by dietary antioxidant curcumin: mechanism of inhibition, specificity and significance," FEBS Letters, vol. 583, no. 22, pp. 3637-3642, 2009.

[60] Z.-Y. Du, Y.-D. Bao, Z. Liu et al., "Curcumin analogs as potent aldose reductase inhibitors," Archiv der Pharmazie, vol. 339, no. 3, pp. 123-128, 2006.

[61] C.-S. Kim, J. Kim, Y. M. Lee, E. Sohn, K. Jo, and J. S. Kim, "Inhibitory effects of chlorogenic acid on aldose reductase activity in vitro and cataractogenesis in galactose-fed rats," Archives of Pharmacal Research, vol. 34, no. 5, pp. 847-852, 2011.

[62] J. Gao, S. Chen, Z. Qiu et al., "Myricitrin ameliorates ethanolinduced steatosis in mouse AML12 liver cells by activating AMPK, and reducing oxidative stress and expression of inflammatory cytokines," Molecular Medicine Reports, vol. 17, no. 5, pp. 7381-7387, 2018.

[63] B.-K. Noh, J. K. Lee, H.-J. Jun et al., "Restoration of autophagy by puerarin in ethanol-treated hepatocytes via the activation of AMP-activated protein kinase," Biochemical and Biophysical Research Communications, vol. 414, no. 2, pp. 361-366, 2011.

[64] A.-Y. Na, E.-J. Yang, J. M. Jeon, S. H. Ki, K.-S. Song, and S. Lee, "Protective effect of isoliquiritigenin against ethanol-induced hepatic steatosis by regulating the SIRT1-AMPK pathway," Toxicological Research, vol. 34, no. 1, pp. 23-29, 2018.

[65] K. H. I. N. Madushani Herath, J. Cho, A. Kim et al., "Phenolic acid and flavonoid-rich fraction of Sasa quelpaertensis Nakai leaves prevent alcohol induced fatty liver through AMPK activation," Journal of Ethnopharmacology, vol. 224, pp. 335$348,2018$. 


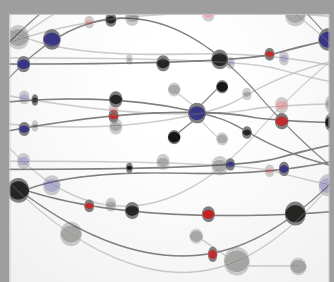

The Scientific World Journal
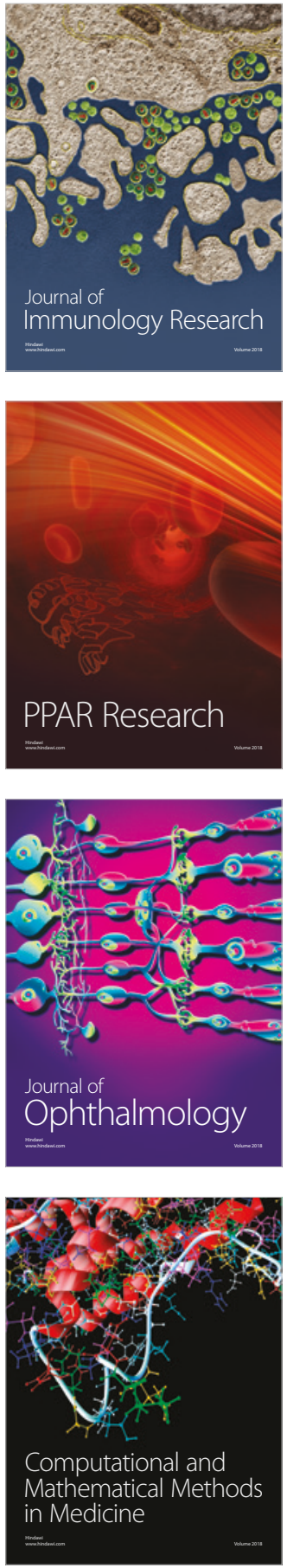

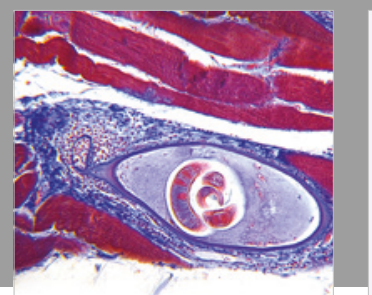

Gastroenterology Research and Practice

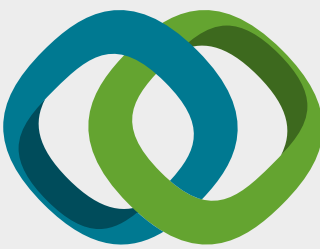

\section{Hindawi}

Submit your manuscripts at

www.hindawi.com
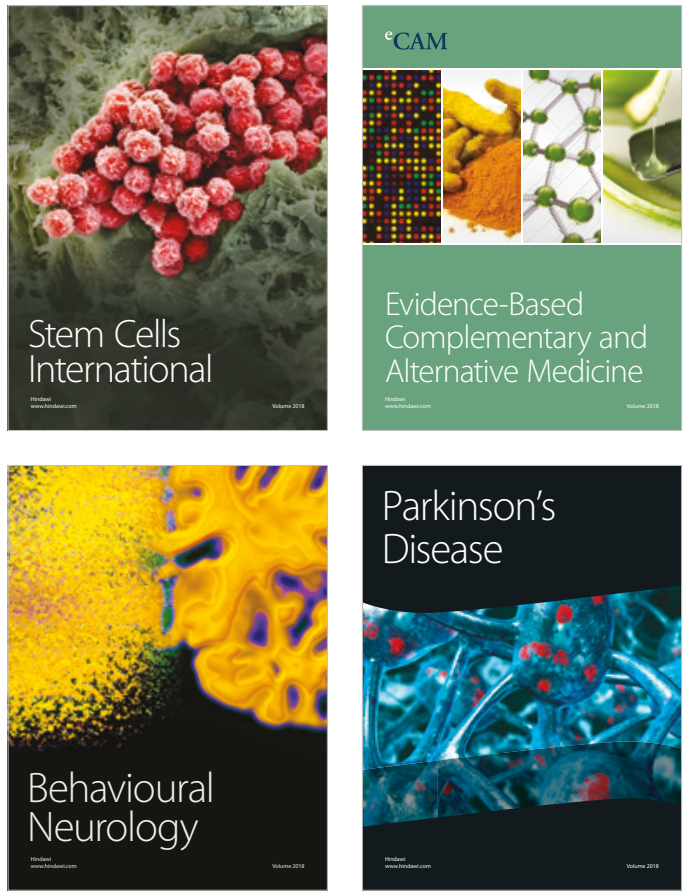

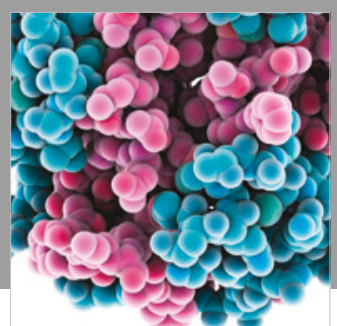

ournal of

Diabetes Research

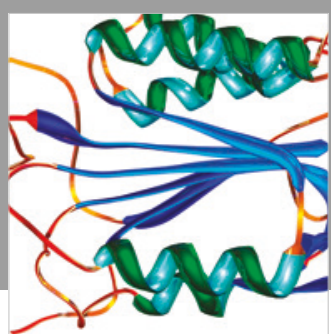

Disease Markers
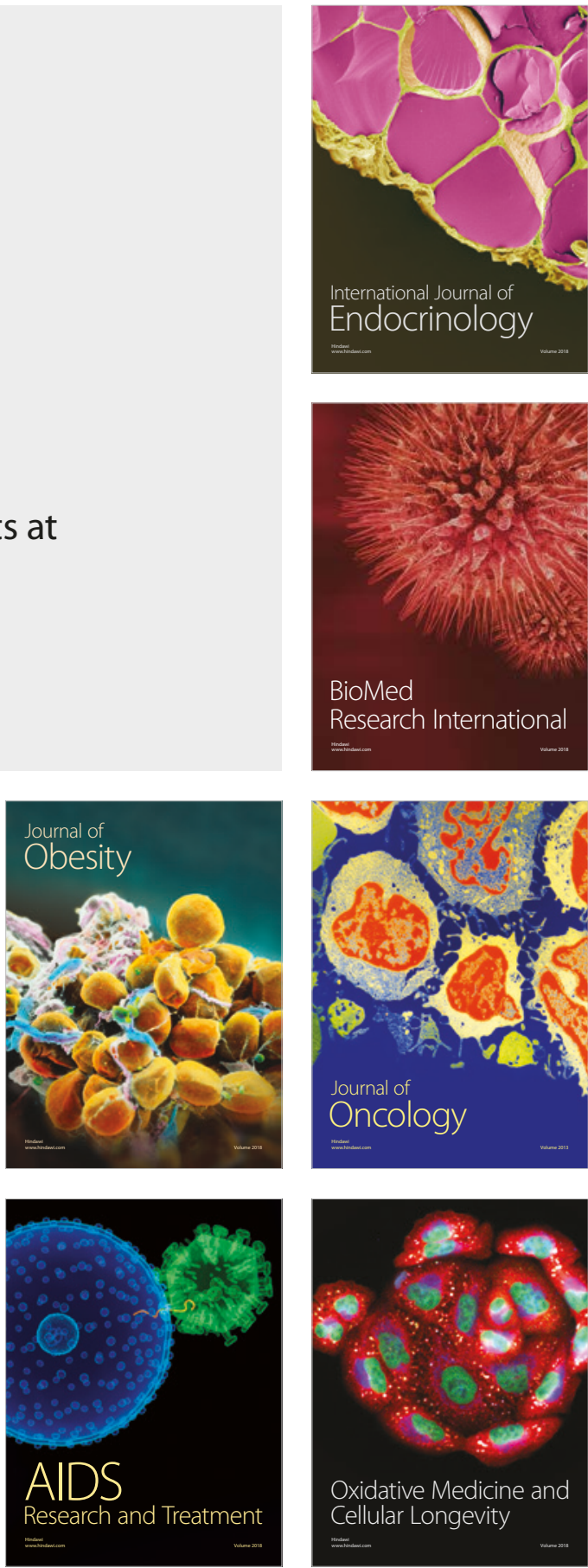